\title{
ALTERAÇÕES CARDIORRESPIRATÓRIAS DA ANESTESIA GERAL EM EQÜINOS, COM ROMIFIDINA, TILETAMINA/ZOLAZEPAM E HALOTANO'
}

\author{
CARDIOPULMONARY ALTERATIONS WITH ROMIFIDINE, TILETAMINE/ZOLAZEPAM \\ AND HALOTHANE IN HORSES
}

\author{
Autor: Alexandre da Silva Polydoro \\ Banca Examinadora: João Eduardo Wallau Schossler ${ }^{3}$ \\ Karin Erica Brass ${ }^{4}$ \\ Daniel Roulin Stainki ${ }^{5}$
}

A anestesia em eqüinos, apresenta uma série de dificuldades, sendo considerada por muitos autores como uma das principais causas de óbito no período trans-operatório. Nos últimos anos, uma série de fármacos vêm sendo utilizados em eqüinos para contenção farmacológica e como protocolos de anestesia geral para a espécie. Neste estudo objetivou-se verificar as alterações cardiorrespiratórias da anestesia geral, em eqüinos, com romifidina, tiletamina / zolazepam e halotano. Foram utilizados 10 eqüinos, em nível experimental, com peso médio de $443,0 \pm 30,07 \mathrm{~kg}$, de ambos os sexos, os quais foram submetidos a avalia- ção cardiorrespiratória pela mensuração dos parâmetros de freqüência cardíaca e respiratória, pressão arterial média (invasiva), equilíbrio ácido-base (hemogasometria arterial) e perfil hematológico (hematócrito, proteína plasmática total e glicemia). Foram mensurados os tempos de indução ao decúbito (em segundos) e o temo de recuperação (minutos) à estação. O protocolo anestésico empregado constou de medicação pré-anestésica com romifidina $(80 \mu \mathrm{g} / \mathrm{kg}$, via intravenosa), indução com a associação tiletamina/ zolazepam $(1,1 \mathrm{mg} / \mathrm{kg}$ em solução a $5 \%$, via intravenosa) e manutenção com halotano, utilizando oxigênio a

\footnotetext{
${ }^{\mathrm{l}}$ Dissertação apresentada ao Curso de Pós-graduação em Medicina Veterinária, área de concentração em Cirurgia, Centro de Ciências Rurais, Universidade Federal de Santa Maria (UFSM) em 15.08.96.

2 Médico Veterinário, Pós-graduando em Medicina Veterinária, Rua Padre Anchieta 66/301, 92110-050, Canoas, RS. Autor para correspondência.

${ }^{3}$ Médico Veterinário, Professor Adjunto, Departamento de Clínica de Pequenos Animais, UFSM.

${ }^{4}$ Médico Veterinário, Professor Adjunto, Departamento de Clínica de Grandes Animais, UFSM.

${ }^{5}$ Médico Veterinário, Professor, Pontificia Universidade Católica, PUC Campus II, Uruguaiana, RS.
}

Ciência Rural, v. 27, n. 1, 1997. 
$100 \%$, num fluxo de $10 / / \mathrm{min}$ como, gás diluente. Os tempos para as coletas das amostras e registro dos dados foram $T_{0}$ (valor basal, anterior a administração da medicação pré-anestésica), $T_{1}$ (10 min após a medicação pré-anestésica), $T_{2}$ (após indução anestésica), $T_{3}$ (aos 15 minutos de manutenção com halotano), $\mathrm{T}_{4}$ (30 min de manutenção), $\mathrm{T}_{5}$ (45 min de manutenção) e $T_{6}$ ) 60 min de manutenção). A técnica anestésica demonstrou que após a administração de romifidina, houve facilidade de manipulação no período préanestésico, que a indução com tiletamina/zolazepam é suave e destituída de excitação ou movimentos involuntários, promovendo uma adequada condição para a intubação orotraqueal e transição para a anestesia inalatória. A recuperação à estação mostrou-se sem intercorrências. Houve alteração significativa nos parâmetros de freqüências cardíaca e respiratória e pressão arterial média. Os dados obtidos referentes ao equilíbrio ácido-base e perfil hematológico de hematócrito, proteína plasmática total e glicemia também estiveram significativamente alterados nos tempos estudados. A técnica anestésica, associada ao decúbito lateral, produziu acidose respiratória com acidemia. Após a indução anestésica ocorreu hipoxemia transitória, contornada pelo início de administração de oxigênio a $100 \%$ como diluente do agente de manutenção anestésica. Como conclusão deste estudo podese recomendar, como protocolo de anestesia geral em eqüinos, a utilização de romifidina como medicação pré-anestésica, indução com tiletamina/zolazepam e manutenção com halotano, prevendo-se possíveis alterações cardiorrespiratórias que não devem ser consideradas como fator limitante de uso.

Palavras-chave: anestesia geral, eqüinos, romifidina, tiletamina/zolazepam.

Equine anesthesia has been considered by many authors as one of the main death causes in the transoperative period. In the last few years, many drugs have been used in this species in order to obtain chemical restraint or general anesthesia. The purpose of this study was to verify the cardiopulmonary changes in equine general anesthesia with romifidine, tiletamine/zolazepam and halothane. Ten horses, male and female, with a mean weight of $443.0 \pm 30.07 \mathrm{~kg}$ were used in this study. Cardiopulmonary function, acid-base status and hematologic profile were evaluated, monitoring cardiac and respiratory rates, mean arterial pressure, arterial blood gas, hematocrit, total plasmatic protein and blood glucose. Time form induction until recumbency and from recovery to stand position were measured. Intravenous romifidine $(80 \mu \mathrm{g} / \mathrm{kg})$ was administered as preanesthetic medication, tiletamine/zolazepam $(1.1 \mathrm{mg} / \mathrm{kg})$ as induction drug and halothane, with $100 \%$ oxygen in a $10 \% / \mathrm{min}$ rate, as maintenance gas. The time for data recording and sample withdrawing were $T_{0}(10 \mathrm{~min}$ prior to preanesthetic medication), $T_{1}(10 \mathrm{~min}$ after preanesthetic medication), $T_{2}$ (after induction), $T_{3}$ (after 15 min of maintenance with halothane), $\mathrm{T}_{4}$ (30 min of maintenance), $T_{5}$ (45 min maintenance) and $T_{6}$ (60 min of maintenance). Romifidine administration provided easy handling of the animals and tiletamine/zolazepam, smooth induction with neither excitement nor involuntary movement leading to an adequate orotraqueal intubation and inhalation anesthesia. No problems were shown in the recovery period until the animals were standing. Significant changes were found in the cardiac and respiratory rates and in the mean arterial blood pressure. Acidbase status, hematocrit, total plasmatic protein and blood glucose were also significantly altered. The anesthetic technic and the lateral recumbency produce respiratory acidosis with acidemia. Transitory hipoxemia was observed after the anesthetic induction and was corrected when the anesthetic gas was administered with $100 \%$ oxygen. After conclusion of this study, the administration of romifidine as preanesthetic medication, tiletamine/zolazepam as induction drug and halothane as maintenace agent can be recomended as a protocol of general anesthesia in horses. The cardiopulmonary changes that can be expected should not limit the use of this drug combination.

Key words: general anesthesia, equine, romifidine, tiletamine/zolazepam. 